magazine that has grown into something else. The Sewanee Review, The Southern Review, The Kenyon Review, The Yale Review, and The Virginia Quarterly Review are described as "fellow travelers" of little magazines. Not mentioned at all, not anywhere in the book, are such magazines as The American Scholar, The Antioch Review, Science and Society.

Interesting as many of the details are in this section, its ineffective organization and incompleteness make it less important (and useful to librarians) than the latter half of the book, which is given over to a two-part bibliography-the much larger first part to little magazines, the second to the fellow travelers of little magazines-and a first-rate index. Reading the history section, for instance, leaves one quite unprepared to discover that of the 540 little magazines listed in the first bibliography, I 34 were published outside the United States-in such countries as England, France, Mexico, Australia, Ireland, Germany, Denmark, and Russia. (An even larger percentage of the fellow travelers are foreign, 43 out of a total of 96.)

The significance of the geographical spread of the little magazine becomes clearer when one examines the informative bibliographical notes under particular entries. Clearly one of the most important results of the little magazine - and in some instances it was an avowed purpose-was cultural interchange between the nations. Translations and critical estimates of foreign authors have been a frequent feature of the little magazine at all times in the last thirty-five years. Interestingly enough, the authors list the publication date of the first modern little magazine as I89I. They might well have made something of the fact that this was the year in which Congress passed the International Copyright Bill. For the act gave American literature a chance to come of age in relation to other literatures; American writers were freed from the frequent practice of foreign pirating and from the unfair competition that existed when foreign fiction and magazine articles could be republished here without the consent of the authors. The little magazine, more than any other part of the publishing industry, seems to have taken advantage of the opportunity. Be that as it may, cultural and literary interchange with other countries has been as much a mark of the little magazine as the publication of experimental writing.

Digging out the elusive facts about brief, fly-by-night journals published over half the world is not the easiest of tasks, and it was a foregone conclusion that a number would be missed. Yet I am sure of only one omission-The Wastebasket published in the Middle West (at St. Paul?) about the end of World War I. For the care of detail and intensive labor lavished on their bibliography, the authors (and presumably Miss Ulrich in particular) are to be congratulated. For the literary researcher and the librarian they have provided a wealth of material which should be useful for some time to come.-Paul Bixler.

\title{
Books and Libraries in Wartime
}

Books and Libraries in Wartime. Edited by Pierce Butler. Chicago, University of Chicago Press, 1945.

In the spring of 1944 ten lectures were delivered under the auspices of the Graduate Library School, University of Chicago, to describe the impact of war on libraries, books, the press, radio, and motion pictures. The volume under review, published a year and a half after the event, contains eight of the lectures, well-edited by Professor Butler. It is unfortunate that they did not appear in print earlier. Timeliness is of minor importance in presenting results of systematic research, but a collection of essays on current trends and events loses much of its value by delay in publication. The fact that some of the contributors did pay attention to postwar problems, however, renders publication at so late a date somewhat more justifiable.

To university and research librarians, the contributions by MacLeish, Beals, and Butler will be of greatest interest. MacLeish's statesmanlike address shows how vital research libraries are to the security of a free nation. Library materials should not serve any particular group but the entire generation of living men. Such an ideal is to be 
reached through world-wide interlibrary loans aided by photographic reproduction, more regional union catalogs, and international division of responsibility in acquisition policies.

Beals describes, in impressionistic fashion, the effect of war on university libraries, with special reference to the destruction of research collections, cuts in student enrolment, disruption of faculties, restriction on construction of new buildings, depletion of library staffs, increased government publishing, and the closing of foreign book markets. For the postwar period he predicts reduced reliance upon library classification and wider use of subject catalogs and bibliographies. $\mathrm{He}$ is also concerned about the distribution of confidential and secret documents after military security restrictions have been removed, a problem today handled on a national scale by the Office of the Publication Board, U.S. Department of Commerce, although not quite in the fashion envisaged by Beals in 1944 .

Butler's attention is focused on war's destruction of rare books, manuscripts, historical records, and the dissolution and reshuffling of library collections. His elegantly written account is enriched by anecdotes and illustrative historical references. Impartial observers might question his statement that the westward stream of rare books from Europe to the United States during the inflation following the First World War was a "glorious" chapter in American library history.

Brand deplores the tendency of publishers to cater to the taste of the masses, although he fails to show how such a trend is related to the occurrence of war. More concerned about "culturally worth-wnile" books than profits, he expresses the opinion that reading will reduce the "cultural lag in the United States," but leaves the reviewer in the dark as to his definition of "cultural lag" and fails to specify in what manner reading is to contribute to the process.

Contrasting best sellers of the two World Wars, Carnovsky concludes that World War II produced better and more serious books. In addition, he attempts to describe what the general public read in World War II. A week's circulation of a suburban community library (Montclair, N.J.) is taken as partial evidence for such inferences as the following: More women and fewer draft-age men borrowed books; most books borrowed were of recent date; no evidence of a return to religion; greater interest in books on Russia than Japan. Comparison with a prewar sample of library loans in terms of categories related to some meaningful sociological or psychological hypothesis might have brought to light additional and more reliable facts about book borrowing during the war.

The inequities and excesses of military censorship are criticized by Mowrer, his special target of attack being the Navy. To improve conditions he enumerates the principles that should govern the administration of war correspondents. Although admitting that war reporting was not always objective and fair, he commends newspapers for having done a good job.

Lasswell discusses the use of radio and movies as political weapons, with special reference to German propaganda. He stresses the importance of monitoring of broadcasts and advocates quantitative analysis of the content of communications, adding little to the methodology outlined in his previous publications.

Trautman's straightforward report on the Army library program includes a list of book selection principles, slightly oversimplified. He expresses the hope that reading habits developed by soldiers will be carried over into civilian life.

On the whole, the volume covers too wide a territory without sufficient penetration. Books contributed heavily to the war effort. Libraries in combat areas were destroyed. Academic libraries in the United States were neglected during the war. Public libraries lost some patrons. Freedom of speech was curtailed. These are some of the themes elaborated on by the contributors, but objective evidence still remains to be presented.Robert H. Muller. 